\begin{tabular}{lcc}
\hline Sournals & $\begin{array}{c}\text { INTERNATIONAL JOURNAL OF } \\
\text { INDUSTRIAL } \\
\text { ORGANIZATIONAL LEADERSHIP }\end{array}$ & MANAGEMENT \\
& INSTITUTE \\
\hline
\end{tabular}

\title{
Cultural background of governance style and quality in Turkey: An introduction
}

\author{
Murat Ertuğrul
}

Faculty of Economics and Administrative Sciences, Anadolu University, Turkey

\begin{abstract}
Keywords:

Governance, Corporate Governance, Turkey, Culture

Correspondence: mertugrul@amadolu.edu.tr

Governance is a term that has gained popularity and has been used by academics and institutions such as UN, IMF and World Bank since 1990s. The term may be defined in a broad manner as "the processes of interaction and decision-making among the parties involved in a collective problem". There are different governance perspectives for different aims. Corporate governance, for example, consists of the processes, customs, policies, laws, and institutions affecting the way people direct, administer or control a corporation. Corporate governance may play an important role especially for the developing countries. They need capital inflows that is affected by sound corporate governance considerably. Turkey is one of the most highlighted emerging economies. In practice, there are some shortcomings in corporate governance compliance in Turkey. In this study, it is aimed to go further than current literature done towards cultural and historical roots which has potentially big impact on the present understanding and compliance of corporate governance in Turkey. The main tool adopted for this aim is closing the gap between respectable studies on the cultural roots of economic understanding of Turkey and studies on corporate governance in Turkey. This paper is presented to share first impressions of this effort.
\end{abstract}

In today's meaning, corporate governance has been greatly considered as the subject of significant debate in USA and around the globe since the late 1970s. But in essence, it is not that new. Corporate governance is mainly a western concept. Western capitalist culture and its experiences lie beneath the corporate governance comprehension. Some of those main experiences and contexts are principal-agent problem, shareholder welfare and stakeholder view, corporate social responsibility, etc. This understanding has emerged in a long time. Corporate governance has been formed in the western world. A huge amount of literature and 
debates on those issues has arisen. Though this literature may be indirectly associated to the developments of a longer time horizon, the formation of the literature can be referred to big crash in 1929. Some different kinds of capitalism flavors such as shareholder capitalism, family capitalism, bank capitalism and state capitalism emerged related to all experiences of this period. It should be stressed that no country is a pure example of one.

It is a widely accepted phenomenon that the natural result of good corporate governance on different stakeholders is a more robust economic structure. Hence, good corporate governance is a tool for socio-economic development. It is established by McKinsey Global Investor Opinion Survey of over 200 institutional investors which was updated in 2002, that $80 \%$ of the respondents would pay a premium for well-governed companies. It is claimed that the lack of corporate governance is one of the main reasons behind financial crises and corporate scandals around the globe. The lack of corporate governance mechanisms in the Asian countries infected during the 1997 crisis is assumed as one of the main structure behind the crisis.

Turkey is a highlighted emerging economy which attracts attention with the qualities of economic size, population, location, recent economic performance, and noteworthy increase in FDI and European Union accession process. Because of all the factors mentioned above, Turkey is one of the countries which need a sound corporate governance the most but for good corporate governance, need and public volition may not be enough.

In our view, Turkey's capitalist history is somehow different from western one. Turkey is neither a definite western country nor an eastern one. Turkey has a unique economic understanding and culture which comes from its unique history. Thus, possibility of implementing western-culture based corporate governance principles just by transplanting them is questionable. Capital Markets Board (CMB) of Turkey published corporate governance principles for Turkey in 2003 and last revision was made in 2011. Indeed, CMB indicates that the particular conditions have been taken into consideration; but there is a doubt if these considerations are deep enough and connected to the cultural and historical roots behind the current comprehension. Results of the studies on corporate governance compliance in Turkey, mentioned below, support this view.

The gap in this area has two dimensions. First gap is insufficient literature on the aspects which are main drivers of corporate governance such as agency theory, shareholder and stakeholder perspectives, and cost of capital and corporate social responsibility. The second gap is between the studies on current corporate governance compliance level and the studies on cultural roots that lie behind the economic comprehension in Turkey.

This study aims to form a first step of a deeper investigation on the cultural factors lie beneath the corporate governance compliance in Turkey. In this way, it is expected to flash on the current level and understanding of corporate governance and to make the way to go clearer. There is a sound literature, organizations, and volition on corporate governance in Turkey. There are also very deep and respectable studies on cultural roots of economic understanding of Turkey but there is a gap between those two fields. The former does not go to the roots enough and the latter does not connect the roots to present and to the economic reality. Therefore, there is a need to connect this understanding to corporate governance perception in Turkey to offer a better landscape for corporate governance in Turkey. This will 
allow the corporate governance community to understand the origins of weaknesses and shortcomings, then, to offer more realistic solutions.

\section{Corporate Governance in Turkey}

\section{A Snapshot of the Landscape of Corporate Governance in Turkey}

Main characteristics of corporate governance application in Turkey are as follows:

After OECD's publication of reference Corporate Governance Principles in 1999, Corporate Governance Working Group formed by TÜSİAD prepared a report called "Corporate Governance-The Best Compliance Code" in 2002; CMB published corporate governance principals in 2003 and revised in 2011; "Comply or Explain" basis is adopted as it is in UK model; a corporate governance index has been calculated in Borsa Istanbul (former Istanbul Stock Exchange) since August, 2007; there are 51 companies covered by the index as of July, 2015 that meet the requirements. Besides six private companies and one NGO had their corporate governance grade calculated voluntarily; new commercial code is effective as from January, 2011 which is expected to empower corporate governance environment; family company form is common; according to a survey on ISE100companies released at the end of 2007, 4 companies are on "very good" level in corporate governance while 10 of them are "good", 12 of them are "medium", 57 of them are "low", and 17 of them are "striving"; the board of directors of Turkish companies are mainly composed of the major shareholders or in other words, the owners (Kula, 2005); the ultimate owners of listed companies are mostly individual family members exercising control on cash flow rights through the said pyramidal ownership structures. In some cases ownership structure is organized within a legal form of a holding company which the groups of companies are very similar to Japanese keiretsu; and in regard of auditing, Turkey may be labeled as an insider system country, since Turkish companies exhibit a highly concentrated and centralized ownership structure.

\section{Shortcomings and Weaknesses}

It is worth to remember the four main dimensions of corporate governance here to be able to refer back when necessary. Equality refers to equal treatment of mangers with shareholders and stakeholders in all activities of the company; therefore equality aims to prevent potential conflicts of interest. Transparency is the principal aiming to disclose financial and nonfinancial information of the company to the public on time, and in an accurate, complete, and clear manner. Reaching the information excluding the trade secrets should be at low cost and easy. Accountability gives the board of directors the obligation of accounting to the company and to the shareholders. Responsibility necessitates the conformity of all operations of the company with the legislation, articles of association, and regulations together with the audit thereof. Shallow markets with less institutional investors and hard-to-predict macro-economic structure do not incent companies to adopt good governance principals.

If one views the corporate structure and market characteristics in Turkey, he/she may realize the need of further improvements in the points of control and disclosure of related party transactions, self-dealing, the protection of minority shareholders, and the role of the board in overseeing shareholders' rights. 
According to OECD Report in 2006, some of the existing limitations can be addressed only by the private sector including controlling shareholders, board members, senior management, company advisers, auditors, and investors. Particularly, board members and controlling shareholders require to present that they are sticking to the spirit and not just the letter of the relevant standards (Murthy, 1998). Investors need to become more informed and to employ more practical market discipline.

La Porta, López de Salinas, Shleifer, and Vishny (1999) stated that the most usual system of corporate governance in the world is family capitalism. A country's large corporations are in the grip of its wealthiest few families in family capitalism. This situation might emerge if investors are greatly mistrustful of most companies and prefer to give their investment decisions based on reputation. Family capitalism also has its problems. Corporate governance is highly concentrated in the hands of a few families in many countries. Since the status quo clearly has benefits to these families, the last feasibility is especially disquieting. So, they may lobby to suppress shareholder rights and competition for savings.

According to a study conducted by Foreign Investment Advisory Service (FIAS), respondents indicated that weakest points of Turkey are instability, excessive bureaucracy, judgment system, tax system, corruption, insufficient substructure, and unregistered economy. Another study conducted by TKYD and Boston Consulting on the managers of 1000 largest companies of Turkey reflects that corporate governance compliance needs some improvements. The priorities are transparency, structural planning for governance and sliding the boards from traditional executive role to the new role of auditing and supervision. Some of the main findings of the study are as follows: Only $14 \%$ of the managers of foreign companies and larger holding companies think that legislative structure and business environment are convenient for corporate governance application in Turkey; besides, $91 \%$ of the respondents think that transparency is a main problem and without a solution, more steps on sound corporate governance are not possible; moreover, $90 \%$ of the companies of the respondents release annual report but $44 \%$ of them put it into the web site; following this, boards are too executive; in addition, special sub-committees, for example for finance and law, are not common; capital Market is not efficient. This delays results, thus, weakens corporations' wish to bear the costs; also, minority shareholders' rights are weak in Turkey because of family capitalism form and controlling owners of the companies; furthermore, $31 \%$ of public companies do not have an Investor Relations department and $51 \%$ of respondents do not recommend to be a minority shareholder in Turkey; finally, $80 \%$ of the respondents think that in their companies, board member election process is clear and $66 \%$ of them think board's decisions are not dependent on one person's opinion.

As it can be seen under the light of the text above, the scores of Turkey for four main dimensions of corporate governance are the same which means they are insufficient.

\section{Culture and Corporate Governance}

Good corporate governance seeks to promote society, employment, responsibility, accountability, probity, transparency, minority shareholders' and stakeholders' rights, democratic ideals, etc. One can easily say by looking at these aspects that corporate 
governance is tightly connected to culture. With a cultural background skeptical about transparency, a country cannot obtain transparency by releasing some written principles.

\section{The Literature Review}

Morck and Steier (2005) listed four main factors laying behind the different corporate governance systems of countries. First of them is "accidents in history". For example, following the experience of 1720, French public opinion improved a violent distaste for anything to do with financial markets. A similar opinion was expressed in the Netherlands. Second factor is "ideas". Wars, upheavals, and many other catastrophes influenced many countries simultaneously but activated various reactions in different countries - perhaps relying on the popularity or unpopularity of definite ideologies at that point in time. Third factor is "families". Burkart, Panunzi, and Shleifer (2003) concluded that the separation of ownership and management is an indication of a superior corporate governance environment. The deficiency in such separation and the prevalence of family firms is conformation of financial underdevelopment. The fourth and last factor is "origins". Much recent work propose that the institutional differences between modern countries arise from differences in their preindustrial economies; there lies a sincere belief that centuries' past happenings and circumstances constrain today's decision makers and institution builders.

Stulz and Williamson (2003) claim that extremely ingrained cultural elements establish economic prosperity in advance. The first two economic powerhouses of modern Europe, namely Britain and the Netherlands were firmly Protestant, as were the principalities that became Germany.

An alternate approach to predestination, more useful to economic analysis, refers to Haber's (1999) argument that various countries have various economic institutions customs, cultures, and traditions as well as legal systems - and that these institutions show how people act and thus, what sorts of public and private investments are achievable.

Chinese listed firms will be ritualistic in financial disclosure because Chinese culture is characterized by high power distance, collectivism, and especially Confucianism. They routinely adhere to minimum standards and that such positions will moderate the effects of corporate governance (Gibbins, Richardson, \& Waterhouse, 1990). Confucianism considers loyalty and obedience to authority as playing an indispensable role in constructing and maintaining social order and harmony, a goal cherished by collective society (Jacobs, Gao, \& Herbig, 1995). In this environment there is little variance in minimum disclosure and corporate governance mechanisms have little opportunity to encourage additional voluntary disclosure.

Haniffa and Cooke (2000) analyzed culture, corporate governance, and disclosure in Malaysia. The significance of two corporate governance variables (i.e. family members sitting on board and non-executive chairman) identified in this study indicated the importance of these variables as determinants of voluntary disclosure. The chairman as non-executive director effects the extent of voluntary disclosure negatively. This seems contradictory to agency theory which suggests that a non-executive chair is needed as a check and balance mechanism. Collaterally, this result may be found as a surprise by the relevant authorities in Malaysia which recommended companies to have a non-executive chair as part of good 
corporate governance practice. In our view, this appearance may not be a surprise and is a result of cultural approach which does not want a non-executive chair but they give a chair to a passive non-executive, for example a friend or a family member just to be able to declare that they respect the recommendations of authorities.

The relations between culture and legal rules observed by Licht, Goldschmidt, and Schwarts (2005) support the proposition that, in the long term, formal institutions should be consistent with the informal cultural environment. Regarding the direction of causality, they find evidence that history (colonial rule) may have impacted both levels.

It is frequently claimed that culture adjusts to socio-economic conditions such as democratization and free markets (Kuran, 2004). While such a causal link is plausible, Williamson (2000) surmises that "institutions at this level change very slowly-on the order of centuries and millennia."

Both from a narrow corporate governance context and from a broader perspective, reforms are more probable to succeed if their designers adapted them to the cultural environment. Toward this end, the present framework can be used to assess the suitability of transplanting legal mechanisms from one nation to another (Licht et al., 2005).

\section{An Overview of Turkish Cultural Roots and Corporate Governance}

The critical importance of culture in corporate governance is known. However, in our view, the great treasury on cultural background of Turkey's economic comprehension has not been evaluated effectively. There are esteemed scholars who conducted sound studies in this field. Economic historians, namely Sabri F. Ülgener, Mehmet Genç, and Doğan Avcığlu are some of the pioneers. As mentioned before, we think that there is a gap between these studies and the studies on corporate governance comprehension and compliance in Turkey. In this part, we present an introduction to this gap. It can be said that Sabri F. Ülgener analyzed the issue from the point of view of liberalism. Mehmet Genç roughly has a central position while Doğan Avcioğlu is a well-known leftist scholar.

It worth to introduce the cultural roots of this insufficiency of these four dimensions based on the three scholars' analyses. It should be kept in mind that this is a subjective mentality area, so it can be interpreted differently by everybody. The highlights derived from the three scholars' studies are as follows: According to Genç (2000) Ottoman economic comprehension was seated on a trivet. Foundations of it are provisionism, fiscalism, and traditionalism. In provisionism, state thought that economics is for meeting the needs of the public. Thus, production was not let to aim residuary and export but import encouraged as far as it is for local needs. So, it is clear that the system was not a mercantilism. Fiscalism means maximizing tax revenues of the state as much as possible and maintaining the current level somehow. The principle so deepened that state looked at every economic activity from the point of view of tax. This fisco-centrism caused a myopic view and in our view it appeared as an obstacle in front of rational economic activities. The third leg of the trivet is traditionalism. Traditionalism aimed to maintain the present balances and allocations in the economy. Because of the shortage on production factors, residuary production and import were not permitted because this may have caused a factor deficit in another area. 
According to Ülgener (1981), since Machiavelli, the west shook and moved out of the ties of traditionalism while in Turkey it is still a strong phenomenon even after constitution of the Republic. Some scholars think that even secularism, one of the main components of Turkish revolution, is used by some groups to protect status quo in economic structure.

Some scholars link the backwardness of Turkey to the Asian Production Model of Marx. Avcıoğlu (1977) does not accept that. He argues that peasantry possessed $90 \%$ of the soil they planted and they could hand it down. From the Seljuk times, Turkish land had been a land of traders especially because of the Silk Road. There were sound trade organizations formed by Turkish traders. One of them was Derbend organization who insured the caravans along the road. Evliya Çelebi, the most famous Ottoman traveler in 17th century reported that there are many well organized and equipped villages in Anatolia who had residual production and capital accumulation as a result.

Avcioğlu (1977) argued that Turkey was not in Asian Production Model. One reason of the backwardness of Turkey is disappearance of the Silk road after western geographical discoveries on oceans but the main reason appeared after that. Western world started to be richer by the discoveries. This improved capital accumulation a triggered capitalism. Capitalism did not come in one day. It went ahead and demolished all pre-capitalist system and dominant classes of it by revolution or evolution. According to Avcioglu, imperialism created a society in accordance with its needs with cooperation of a local minority. This project included saving and even strengthening backwardness components.

From this point, we can interpret today's weakness in corporate governance in emerging world as a result of affords of especially local minorities who assume corporate governance as a threat to their status quo. So, even if it is not declared, such classes are in a battle against equality, transparency, accountability, and responsibility.

Ülgener (1981) probably conducted the deepest analyses on the historical mental factors. Ülgener indicates that a strong capitalist class emerged in the west after discoveries and struggled against status quo defender state and the church from time to time. But in Turkey, capitalist class had cringed under pressure of two main classes, namely administrators and scholars. Another issue Ülgener (1981) stressed is grandeur passion. Eastern and Turkish look diverges from western here and trade was done to satisfy this passion. This factor can also be a source of today's insufficiency. Western travelers such as Sonnini mentioned about the non-effective and destructive effect of this cultural aspect.

One more factor analyzed by Ülgener (1981) is unpleasant nature of trade by the side of higher classes. Business is not approved as a pleasant occupation by the higher level classes though they somehow had a share from the profit. Such an administrator's class would not like a shift to a transparent and equal environment which can considerably increase their extremely low cost/benefit ratio.

Another factor that may affect today's view fixed by Ülgener (1981) is weak tendency to calculating, recording, and forming archives. Rentability and feasibility analyses had been a mirage. In our view, it is because of Turkish business community that had never faced a real competitive environment forcing them to be rational and effective. The comfort ability of non-competitive environment without transparency probably motives the delaying corporate governance behavior of Turkish controlling minorities. Because fair players do not abstain 
from recording and monitoring which brings transparency and other components of corporate governance.

Family business and management characterizes Turkish culture. This is probably why separation of ownership and management, increase in distribution of ownership, and shaping boards according to corporate governance principles seem to have some obstacles and weaknesses. Turkish capitalists are still skeptical on professional top level management.

Long term planning, looking at far, assumed unfavorable in Turkish business culture. Especially, in the environments of trade under the control of politics and scholars, today's need was urgent and looking at tomorrow was not approved notably by some religious interpretations. This can be assumed as one of the main reasons of late capital accumulation and capitalism in Turkey. Lack of long-term planning culture in genes, value-maximization, and corporate governance comprehension do not improve as expected.

\section{Discussion and Conclusion}

This study aimed only to open a door to deeper studies to close the gap between recent corporate governance comprehension in Turkey and in its cultural background. It is aimed to introduce first impressions of readings on esteemed scholars who took deep analyses on cultural backgrounds of economic comprehension of Turkey. In this study, some of cultural roots are mentioned which may be the background of recent situation and insufficiency of corporate governance in Turkey.

There are some idioms in Turkish which can be assumed as good indicators of cultural background. Transparency seems as one of the main shortcomings in Turkey. An idiom in Turkish literally means "an arm may be broken but it should stay under the clothing"; this may correspond to the English idiom "don't let it out of this room". Another idiom literally states "one who tells the truth is driven away from every villages" which may correspond to the English idiom "all truth is not always to be told."

Those idioms may give a clue on the cultural outlook on transparency, accountability, and responsibility in Turkish culture. A sound corporate governance seems critical for Turkey but there are some obstacles. Controlling shareholders want to continue controlling everything and they do not support improvements in minority shareholders' rights. Following this, distributed ownership proportion is low and transparency is problematic. Corruption is structural somewhere and transparency efforts face a resistance.

Corporate governance principles are released 12 years ago in Turkey by CMB, but only 51 companies are in the corporate governance index in the stock exchange. A great proportion of top level, managers think that substructure in Turkey is not sufficient for a sound corporate governance.

We share the opinion that a nation cannot be understood without going back to its roots. Due to this, we enhanced readings on economic history which focuses on mental and cultural roots to be able to understand today's Turkey from the point of view of corporate governance.

Under the light of studies up to now, we reached some main aspects of cultural background listed above. In this literature, one can find very valuable points explaining today's weaknesses. So, it is recommended that there might be further studies in this field. It is also recommended that policy makers should encourage studies in this field and utilize the 
outputs. Without such a deeper evaluation, written principles will always have some weaknesses and will not be applied as expected.

\section{References}

Avcıoğlu, D. (1977). Türkiye’nin düzeni. İstanbul: Tekin Yayınevi.

Burkart, M., Panunzi, F., \& Shleifer, A. (2003). Family firms. Journal of Finance, 58(5), 2167-2201.

Genç, M. (2000). Osmanlı imparatorluğu'nda devlet ve ekonomi. İstanbul: Ötüken.

Gibbins, M., Richardson, A., \& Waterhouse., J. (1990). The management of corporate financial disclosure: Opportunism, ritualism, policies, and processes. Journal of Accounting Research, 28, 121-143.

Haber, S. (1999). Industry and underdevelopment: The Industrialization of Mexico. Stanford: Stanford University Press.

Haniffa, R., \& Cooke, T. (2000, August). Culture, corporate governance and disclosure in Malaysian Corporation. Paper presented at the Asian AAA World Conference, Singapore.

Jacobs, L., Gao, G. \& Herbig, P. (1995). Confucian roots in China: A force for today’s business. Management Decision, 33(10), 29-34.

Kula, V. (2005). The impact of the roles, structure and process of boards on firm performance: Evidence endure from Turkey. Corporate Governance: An International Review, 13(2), 265-276.

Kuran, T. (2004). Cultural obstacle to economic development: Often overstated, usually transitory. In V. Rao \& M. Walton (Eds.), Culture and Public Action (Volume 18, pp. 71-90). Stanford, Cal.: Stanford University Press.

La Porta, R., López de Salinas, F., Shleifer, A., \& Vishny, R. (1999). Corporate ownership around the world. Journal of Finance, 54(2), 471-520.

Licht, A. N., Goldschmidt, C., \& Schwartz S. H., (2005) Culture, law, and corporate governance. International Review of Law and Economics, 25(2), 229-255.

Morck, R. K., \& Steier, L. (2005). The global history of corporate governance: An introduction (NBER Working Paper No. 11062).

Murthy, K. R. S. (1998). Corporate governance: A sociological perspective. ASCI Journal of Management, 27(1/2), Select Articles.

Stulz, R., \& Williamson, R. (2003). Culture, openness and finance. Journal of Financial Economics, 70(3) 313-349.

Ülgener, S. F. (1981). İktisadi Çözülmenin Ahlak ve Zihniyet Dünyası. İstanbul: Der Yayınları.

Williamson, O. E. (2000). The new institutional economics: Taking stock, looking ahead. Journal of Economic Literature, 38(3), 595-613. 